\title{
DESCRIPTION OF A RIG FOR THE TESTING OF A PROTOTYPE ENGINE WITH A PNEUMATIC ENERGY ACCUMULATOR
}

\author{
MICHAL GLOGOWSKI', ZBIGNIEW PAWELSKI² \\ Lodz University of Technology
}

\section{Summary}

The principle of operation of an engine with a pneumatic energy accumulator and a test rig built at the Technical University of Lodz, Department of Vehicles and Fundamentals of Machine Design, have been presented in this paper. The test rig was used to test a two-stroke spark-ignition IC engine with a prototype energy accumulator situated in one of the engine cylinders. The instantaneous position of the secondary piston of the energy accumulator was measured with the use of a laser sensor fixed on the cylinder head and the measurement system has been described in this paper. A graph with typical curves representing the engine cylinder pressure and the movement of the secondary piston in the pneumatic energy accumulator has been included, too.

Many attempts have already been made to provide the spark-ignition IC engine with devices of various kinds in order to improve engine performance characteristics. However, none of the solutions proposed have found wider practical application. In the case of a pneumatic energy accumulator with the new design concept as presented here, a broad spectrum of development possibilities can be seen. Therefore, this article will be the first in a series dedicated to the testing and modelling of a spark-ignition engine with a pneumatic accumulator.

Keywords: internal combustion engine, pneumatic energy accumulator, laser sensor, compression ratio, secondary piston.

\section{Introduction}

The traditional piston-crank mechanism in spark-ignition engines has a constant compression ratio. One of limitations to the compression ratio values stems from a hazard of combustion with knocking, which must be avoided at the maximum engine load; it is chiefly for this reason that the compression ratio of an average engine ranges from 8:1 to 11:1. In spark-ignition (SI) engines, the constant ignition ratio results in a drop in the general engine efficiency with decreasing load. However, the idea of variable compression ratio was actually passed over when engines were designed for series production; nevertheless,

' Lodz University of Technology, Department of Vehicles and Fundamentals of Machine Design, 116 Żeromskiego Street, 90-924 Lodz, e-mail: instpojap.lodz.pl, ph.: + 4842 636-22-65 fax 42 631-23-98

${ }^{2}$ Lodz University of Technology, Department of Vehicles and Fundamentals of Machine Design, 116 Żeromskiego Street 90-924 Lodz, e-mail: zbigniew.pawelski@p.lodz.pl, ph.: +48 42 631-23-91 
this may become a subsequent stage of the development of SI engines in the future. There are a great many designs of engines with variable combustion ratio, e.g. MCE-5, SAAB SVC $1.6 \mathrm{~L}$, or Lotus Omnivore.

In the solution covered in the patent application filed with the Patent Office of the Republic of Poland under item P388876 [1] and described here, the compression ratio is automatically controlled by a secondary spring-supported piston located in the cylinder head and constituting, together with the associated components, a pneumatic energy accumulator. Such a solution was tested in a two-stroke engine, with cylinder pressure curves being measured at several loads at a selected engine speed.

\section{Principle of operation of the engine with a pneumatic energy accumulator}

A schematic diagram of the construction of a pneumatic energy accumulator, taken from the patent application, has been presented in Fig. 1. According to the description provided in the application, there are two moving space dividers when cylinder valves are closed. The first one is the crown of the piston (6), which is connected with the engine by kinematic links; the face of the secondary piston (5) constitutes the other one. The behaviour of the first space divider is defined by kinematics of the piston-crank mechanism. The movement of the other one is controlled by the resultant of all the forces acting on the secondary piston, i.e. thrust caused by the pressure prevailing in the engine cylinder, thrust of the pneumatic springs, inertia forces, and friction forces.

The principle of operation of the engine with a pneumatic energy accumulator is as described below. When the engine cylinder pressure overcomes the initial pressure in the tank of the pneumatic spring (2) then the secondary piston (5) goes up and, simultaneously, accumulates energy in the "tank-spring" (2). When the piston reaches its top position, the elastic strain energy accumulated in the "tank-spring" comes to its maximum and all the forces acting on the piston, including the inertia forces, balance each other. The energy accumulated in the "tank-spring" is recuperated when the piston (5) goes back. Then, the piston going down keeps the volume of the combustion chamber on a constant level thanks to the energy of the "tank-spring." The piston approach to its bottom position is controlled by a single-acting pneumatic spring (4) and a single-acting damper (3). The engine cycle modification as presented, related to the end of the compression stroke and the beginning of the expansion stroke, requires the pneumatic energy accumulator designed as a "tankspring" to be highly adaptable so that the cycle could be successfully performed in a wide range of engine speeds and loads. This is achieved by changing the pneumatic spring (2) rate in two ways: by changing the volume of the "tank-spring" with a movable baffle (1) and by changing the pressure in the tank of the pneumatic spring.

The solution applied offers low mass of the secondary piston system, easy control, and relatively compact and simple design. 


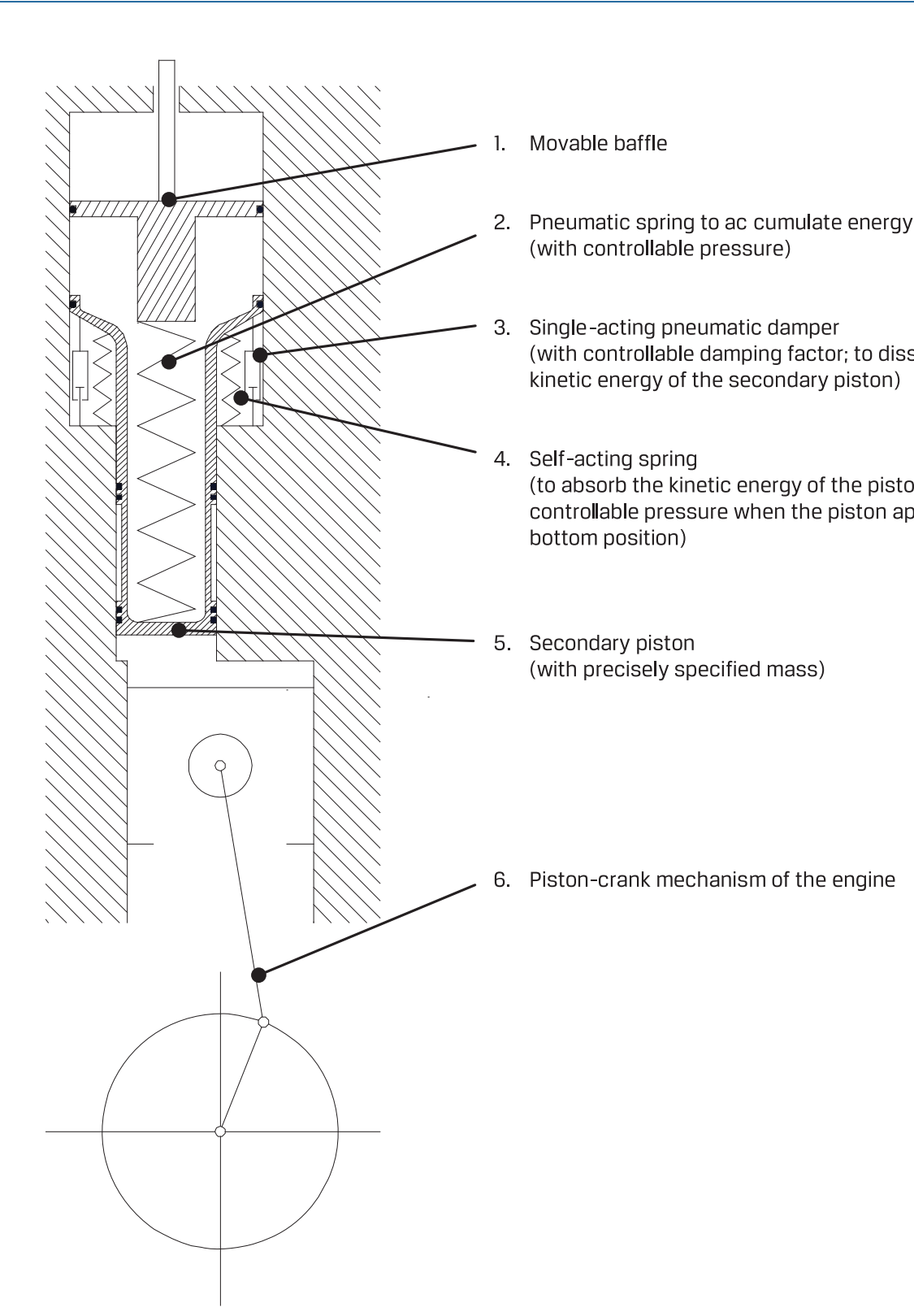

Fig. 1. Principle of operation of the pneumatic energy accumulator. 


\section{Test rig}

The test rig, which was built when the work described in [2] was being done, has been shown in Fig. 2, with the description of the test rig components having been limited to the system part that was related to the supply of air to the energy accumulator. The system built offered full electronic control of air pressure from a control console within a range from 0,1 MPa do $1 \mathrm{MPa}$ bars. Two pressures could be controlled, i.e. the pressures of the air supplied to the main pneumatic spring (2) and to the auxiliary spring (4).

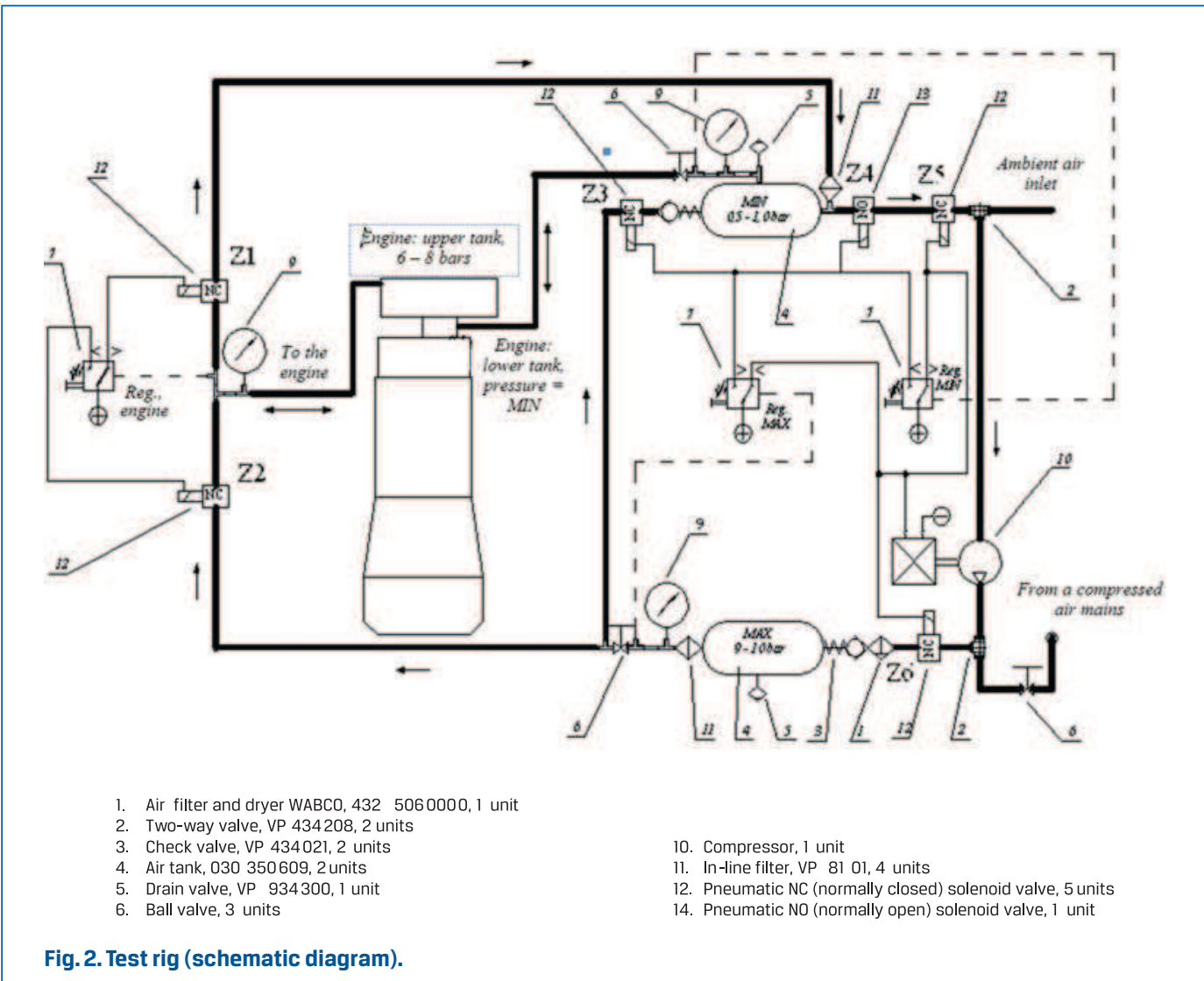

\section{Laser measurement of the position of the secondary piston}

The position of the secondary piston (5) in the cylinder head of the two-stroke engine was measured with the use of a laser distance sensor Baumer OADM 2016460/S14F with measuring range of $30 \div 130 \mathrm{~mm}$, sampling frequency of $1.1 \mathrm{kHz}$, and linearity error of $0.2 \mathrm{~mm}$.

A schematic diagram of the measurement method has been shown in Fig. 3. The measurement was carried out in a measurement space, in which the secondary piston 
was moving. The measurement space was isolated from the environment because of the overpressure prevailing in it. A laser beam going through a sight glass was reflected from the measurement surface and returned to the sensor after having been deflected by an angle that was a measure of the distance between the measurement surface and the sensor. The measurement thus carried out was burdened with errors arising from the refraction of light on sight glass surfaces, but tests carried out made it possible to

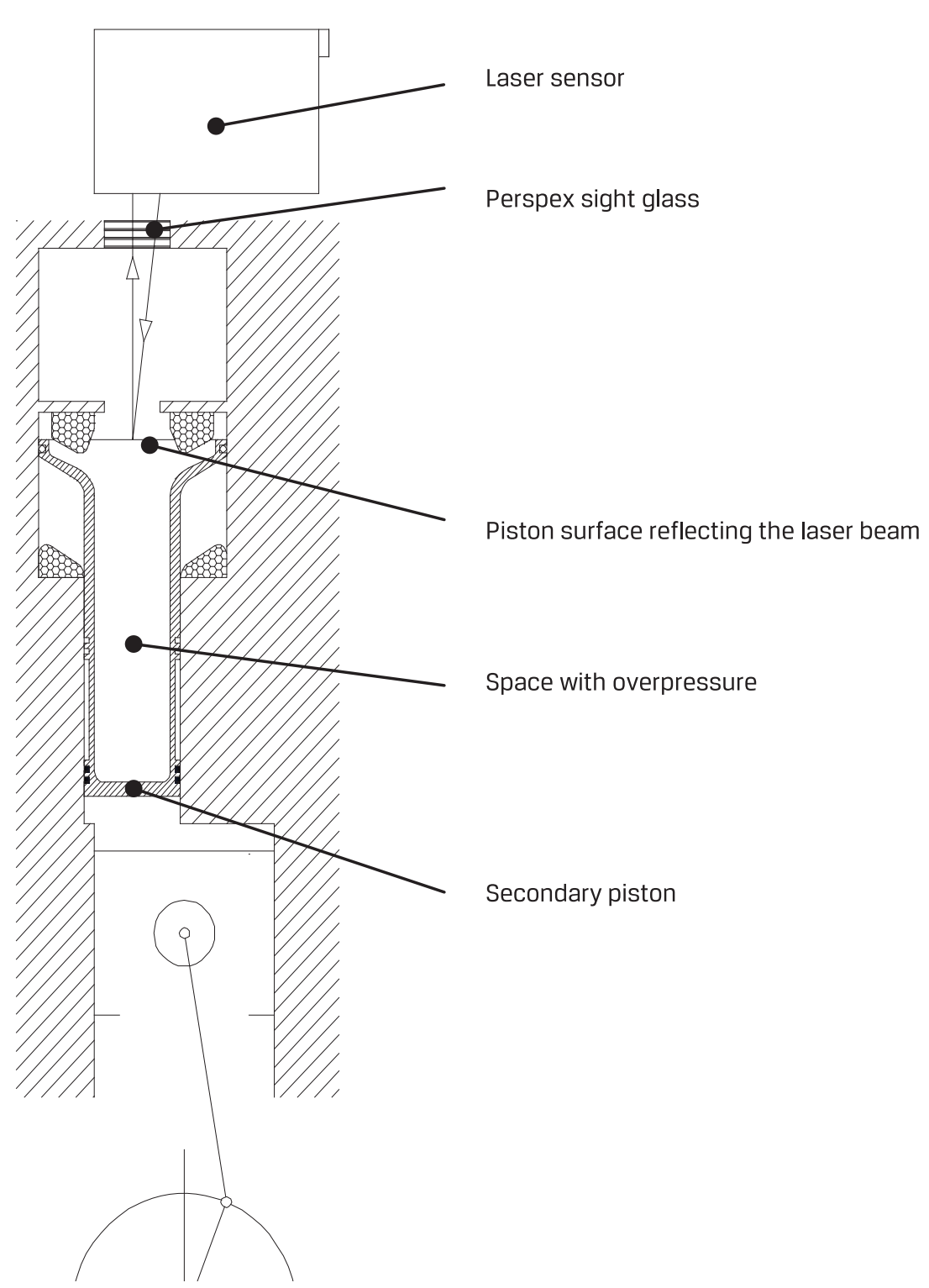

Fig. 3. Piston position measuring system. 
estimate the error; at differential measurements, it could be ignored without detriment to the measurement results. In the whole measurement space, there were particles of oil, which lubricated and cooled the piston/cylinder system. The oil particles also settled on the surface that reflected the measuring laser beam and on the perspex sight glass. This caused the necessity of continuous monitoring of the system operation and resulted in signal fadeouts, which entailed breaks in the measurements. During the breaks, the oil was removed from all the surfaces and, at the same time, the technical condition of the pneumatic energy accumulator was verified.

Engine vibrations were found to be another problem. They caused a physical phenomenon of interference, which was liquidated by the application of a special device that fixed the sensor on the cylinder head. This problem could be solved in two ways: either by fastening the sensor very stiffly, but at a risk of damage to the sensor, or by using an elastic fixture with a vibration damper. At the testing of the prototype, the latter method was employed because of the specific sensor used, for which the acceptable working accelerations were significantly limited.

In result of experiments, the upper surface of the piston was chosen as the element to reflect the laser beam, because it was free of oil deposits. A drawback of such a solution was small width of the measurement area, which required the sensor to be very precisely positioned; moreover, the piston deformations caused by internal stresses could not be taken into account. After an analysis of all the problems related to the measurements carried out, it was found that the sampling frequency of a new sensor should be at least $15 \mathrm{kHz}$ and its accuracy should be of the order of $0.1 \mathrm{~mm}$. Only the use of such a sensor resistant to high acceleration values and rigidly fastened to the cylinder head would ensure adequate measurement accuracy.

\section{Test method}

The test was based on a requirement that the maximum pressure value should not exceed that of the pressure occurring in the engine when the throttle is fully open.

This value was found at the initial stage of the tests to be about $4.5 \mathrm{MPa}$. Then, the geometrical parameters and supports of the secondary piston were determined. Several dozen measurements of pressure curves were also carried out for the modified cylinder in order to develop the energy accumulator design. Following this, a comparative measurement was carried out on a two-stroke engine. Pressure variations were simultaneously measured in two outermost cylinders, the combustion chambers of which have been presented in Fig. 4. Thanks to this, the results obtained for both cylinders could be directly compared with each other in the selected ranges of engine speeds and loads. The analysis was only carried out for the working points where the scavenging in the two-stroke engine, resulting in asymmetry in the process of supply of air-fuel mixture to both cylinders, was not disturbed. Moreover, the influence of the ignition advance angle and the mass of the secondary piston on the cylinder pressure curve was also tested. 


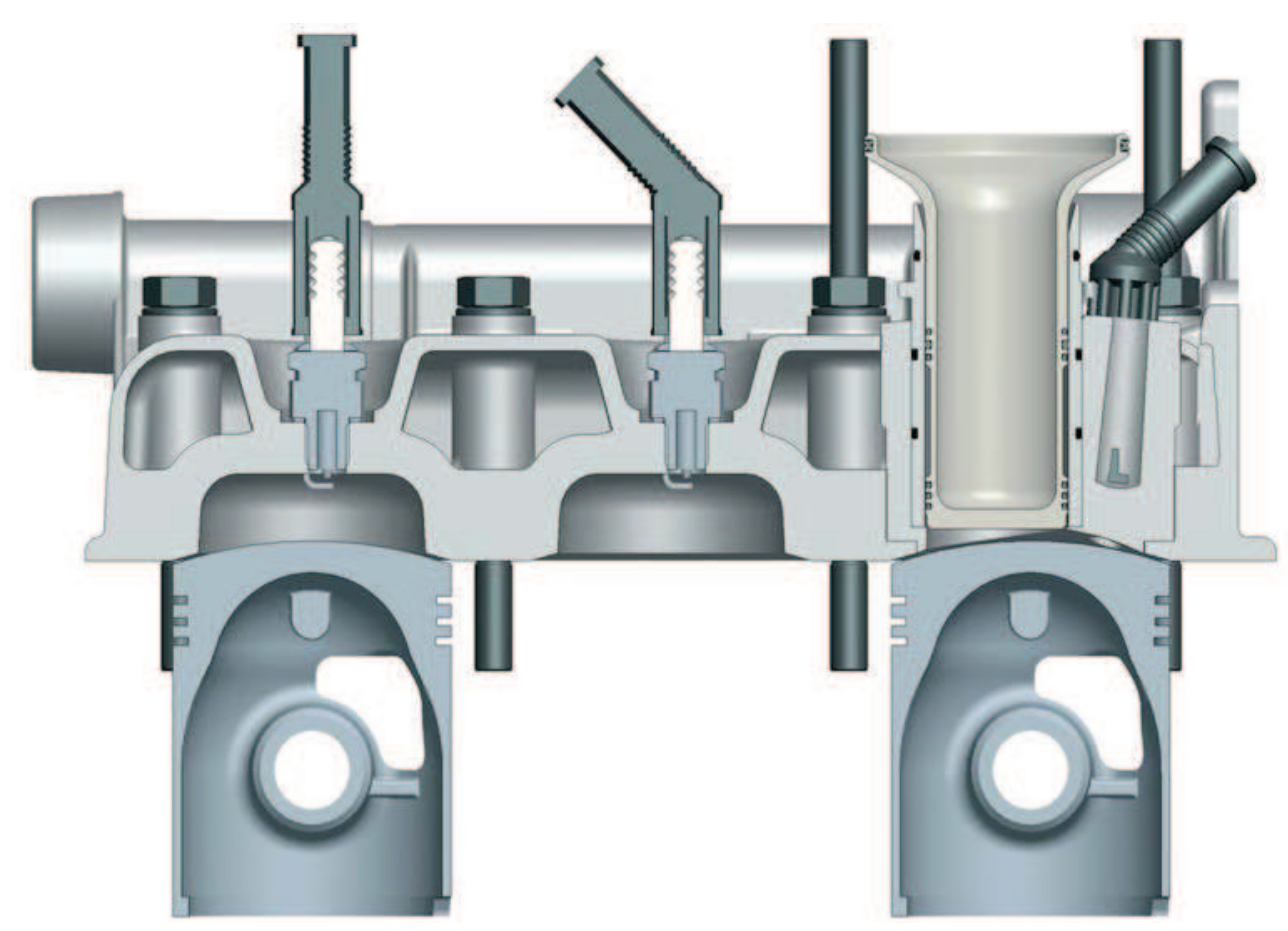

Fig. 4. Combustion chambers of the two cylinders compared with each other.

\section{Example of the measurement results obtained for the two-stroke engine}

An example of loops representing the secondary piston position (dashed line) and the cylinder pressure (full line) vs. relative cylinder volume, superimposed on each other and simultaneously measured on the two-stroke spark-ignition engine, has been presented in Fig. 5. The working parameters of the engine were as follows during the measurement: displacement of a single cylinder - $332 \mathrm{~cm} 3$; throttle opening angle - about $15 \%$; engine speed - 1400 rpm; maximum compression ratio - about 20:1.

The actual cylinder pressure vs. volume curve as presented in Fig. 5 visibly differs from the standard pressure-volume curve measured for a two-stroke spark-ignition engine. Undoubtedly, this has been caused by the functioning of the secondary piston present in the combustion chamber. The movement of the secondary piston at its final stage could be roughly described as oscillating motion with damped amplitude and visible logarithmic damping factor, which evidenced correct functioning of the system to dissipate the kinetic energy of the secondary piston (5) approaching its bottom position, spring (4) and damper 
Cylinder pressure [MPa]

Secondary piston position [mm]

5

4

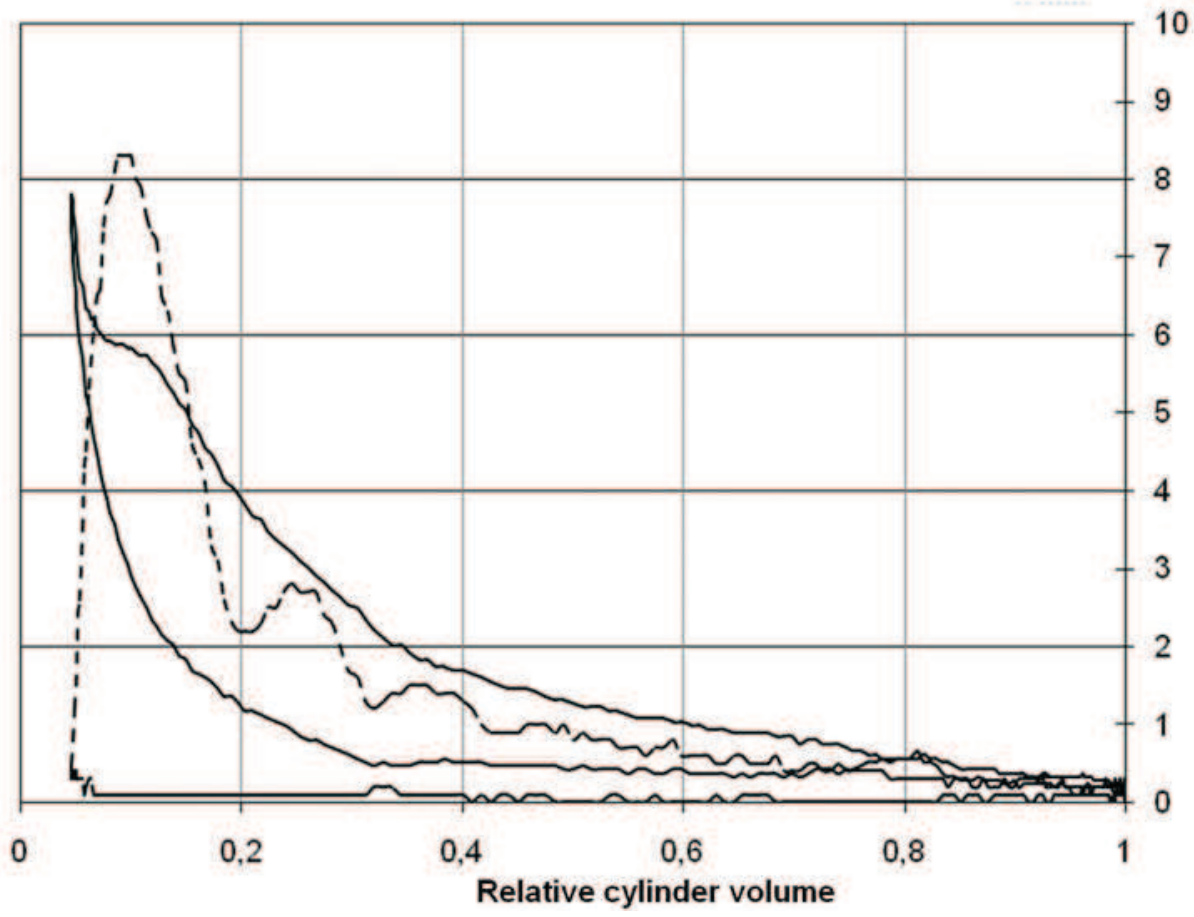

Fig. 5. Actual cylinder pressure and secondary piston position vs. relative cylinder volume.

(3). The curve representing the movement of the secondary piston (dashed line) in Fig. 5 is visibly corrugated. This may be explained by insufficient sampling frequency of the laser distance sensor, which "lost the signal" at higher speeds.

The pressure measurement was also disturbed, which resulted from interferences of electrical nature, becoming particularly well visible in the range of low pressure values. In spite of this, a "shelf" typical for the solution under consideration can be seen. This represents the cycle part where energy recuperation takes place: temporarily, the cylinder volume does not significantly change and, in consequence, the pressure remains constant (hence the name).

\section{Recapitulation}

The structure of the pneumatic energy accumulator proved to be sufficiently durable for the preliminary tests to be carried out. The test rig was developed to such an extent that all the engine and accumulator parameters could be fully controlled. The energy accumulator 
characteristics such as mass of the secondary piston and pressures in the secondary piston supporting springs were preliminarily selected and the impact of these parameters on the cylinder pressure variations at the end of the compression stroke and at the beginning of the expansion stroke was analysed. During the tests, the engine efficiency at partial loads was found to have increased by $30 \%$ and no signs of combustion with knocking were detected despite a very high compression ratio (21:1). Disturbances of engine scavenging prevented the engine tests from being carried out at throttle opening angles exceeding 50\%. Moreover, when the secondary piston (5) approached its bottom position, a pressure was found to occur in the spring (4) that was many times as high as that supplied to the spring (2), which indicated that the mass forces in the system reached very high values. The most troublesome task was found to be the measuring of the secondary piston position with a laser distance sensor. Too low a sampling frequency of the sensor made it impossible for a thermodynamic analysis of the system at higher engine speeds to be carried out. The tests will be continued on a four-stroke engine with the use of a laser sensor with specifications meeting the requirements in the full range of engine loads.

\section{References}

[1] GtOGOWSKI M.: Patent application filed on 27 Aug., 2009 under item P388876.

[2] Technical report of the completion of an author's research project N512 012 31/1068 "Tłokowy silnik spalinowy o regulowanej objętości spalania oraz wewnętrznej akumulacji i rekuperacji energii (Reciprocating internal combustion engine with controllable combustion volume and with internal accumulation and recuperation of energy)".

[3] OSIŃSKI Z.: Teoria drgań (Theory of vibrations). PWN, Warszawa 1980.

[4] WIŚNIEWSKI S.: Termodynamika techniczna (Technical thermodynamics). PWN, Warszawa 1987.

[5] KORDZIŃSKI CZ., POGORZELSKI ].: Małe silniki spalinowe (Small internal combustion engines). WKŁ, 1982.

[6] JĘDRZEJOWSKI J.: Mechanika układów korbowych (Mechanics of crank systems). WKŁ, 1987. 


\title{
OPIS STANOWISKA DO BADAŃ PROTOTYPU SILNIKA Z PNEUMATYCZNYM AKUMULATOREM ENERGII
}

\author{
MICHAL GLOGOWSKI', ZBIGNIEW PAWELSKI² \\ Politechnika Łódzka
}

\section{Streszczenie}

W artykule przedstawiono zasadę działania silnika z pneumatycznym akumulatorem energii oraz stanowisko zbudowane w Katedrze Pojazdów i Podstaw Budowy Maszyn Politechniki Łódzkiej. Na stanowisku przebadano dwusuwowy silnik spalinowy o zapłonie iskrowym z prototypowym pneumatycznym akumulatorem energii, umieszczonym w jednym z cylindrów silnika. Pomiar położenia dodatkowego tłoka z akumulatora był realizowany czujnikiem laserowym zamocowanym na głowicy i został opisany w artykule. Zamieszczono również typowy przebieg ciśnienia w cylindrze i ruchu dodatkowego tłoka w pneumatycznym akumulatorze. Silnik spalinowy o zapłonie iskrowym w swojej historii był już wielokrotnie wyposażany w różnego rodzaju urządzenia mające poprawiać jego parametry, ale próby nie znalazły szerszego zastosowania. W przypadku pneumatycznego akumulatora energii przedstawionego $w$ artykule widać szerokie spektrum możliwości otwierające się przed nową konstrukcją, dlatego artykuł ten będzie pierwszym z cyklu artykułów poświęconych badaniu i modelowaniu silnika o zapłonie iskrowym z pneumatycznym akumulatorem.

Słowa kluczowe: silnik spalinowy, pneumatyczny akumulator energii, czujnik laserowy, stopień sprężania dodatkowy tłok.

\begin{abstract}
1. Wstęp
Tradycyjny układ korbowo-tlokowy w silnikach o zapłonie iskrowym ma stały stopień sprężania. Jednym z ograniczeń wartości stopnia sprężania jest możliwość wystąpienia zjawiska spalania stukowego, które nie może się pojawić przy maksymalnym obciążeniu silnika i głównie $z$ tego powodu wartość stopnia sprężania dla przeciętnego silnika, mieści się w przedziale od 8 do 11. W silnikach o zapłonie iskrowym efektem stałego stopnia sprężania jest spadek sprawności ogólnej silnika wraz ze spadkiem obciążenia. Zmienny stopień sprężania był jednak pomijany przy konstruowaniu silników produkowanych seryjnie, choć w przyszłości może on stanowić kolejny etap rozwoju silników o zapłonie iskrowym.
\end{abstract}

'Politechnika Łódzka, Katedra Pojazdów i Podstaw Budowy Maszyn, ul. Żeromskiego 116, 90-924 Łódż, e-mail instpoj@p.lodz.pl, tel. 426362265 , fax 426312398

${ }^{2}$ Politechnika Łódzka, Katedra Pojazdów i Podstaw Budowy Maszyn, ul. Żeromskiego 116, 90-924 Łódż,

zbigniew.pawelski@p.lodz.pl, tel. 426312391 
Istnieje bardzo wiele rozwiązań realizujących zmianę stopnia sprężania, wśród których należy wymienić silniki: MCE-5, SAAB SVC 1.6L czy Lotus Omnivore.

W artykule opisano rozwiązanie zgłoszone w Urzędzie Patentowym RP pod numerem P388876 [1], w którym elementem regulującym stopień sprężania w sposób samoczynny jest dodatkowy tłok, umieszczony w głowicy silnika, podparty sprężyście i wraz pozostałymi elementami stanowiący pneumatyczny akumulator energii. Proponowane rozwiązanie sprawdzono w silniku dwusuwowym przeprowadzając pomiary przebiegu ciśnienia w cylindrze dla kilku wybranych obciążeń przy wybranej prędkości obrotowej.

\section{Zasada działania silnika z pneumatycznym akumulatorem energii}

Na rys. 1. przedstawiono schemat budowy pneumatycznego akumulatora energii, pochodzący ze zgłoszenia patentu. Zgodnie ze znajdującym się tam opisem w cylindrze silnika (komorze spalania) po zamknięciu zaworów znajdują się dwie ruchome przegrody; pierwszą stanowi denko tłoka (6) związanego kinematycznie z silnikiem a drugą - powierzchnia czołowa dodatkowego tłoka (5). Zachowanie pierwszej przegrody opisuje kinematyka mechanizmu korbowo-tłokowego. 0 ruchu drugiej przegrody decyduje wypadkowa wszystkich sił działających na dodatkowy tłok: parcie czynnika wywołane przez ciśnienie w cylindrze silnika, parcie pneumatycznych sprężyn, siła bezwładności i siły tarcia.

Zasada działania silnika z pneumatycznym akumulatorem jest następująca: w chwili, gdy ciśnienie w cylindrze silnika pokona napięcie wstępne w zbiorniku-sprężynie pneumatycznej (2), dodatkowy tłok (5) unosi się magazynując jednocześnie energię w zbiorniku sprężynie (2). Gdy tłok zajmie najwyższe położenie, wtedy zgromadzona energia sprężysta w "zbiorniku-sprężynie" osiąga największą wartość, a wszystkie siły działające na tłok, w tym siły bezwładności zrównoważą się. Rekuparacja energii zgromadzonej w „zbiorniku-sprężynie" następuje przy ruchu powrotnym tłoka (5). Wówczas opadający tłok dzięki energii ze „zbiornika-sprężyny" podtrzymuje objętość w komorze spalania na stałym poziomie. Kontrolę osiadania tłoka $w$ dolnym położeniu zapewnia pneumatyczna sprężyna jednostronnego działania (4), oraz tłumik jednostronnego działania (3). Przedstawiona modyfikacja cyklu silnika, która dotyczy końca suwu sprężania i początku suwu rozprężania wymaga od akumulatora pneumatycznego w postaci „zbiornika-sprężyny” zdolności adaptacyjnych, takich by cykl mógł być realizowany w dużym zakresie prędkości obrotowych i obciążeń. Uzyskiwane jest to przez zmianę sztywności sprężyny pneumatycznej (2) na dwa sposoby: zmianę objętości „zbiornika-sprężyny" ruchomą przegrodą (1) oraz przez zmianę ciśnienia panującego w zbiorniku.

Zastosowane rozwiązanie daje: małą masę dodatkowego układu, łatwy sposób sterowania oraz stosunkowo zwartą i prostą konstrukcję. 


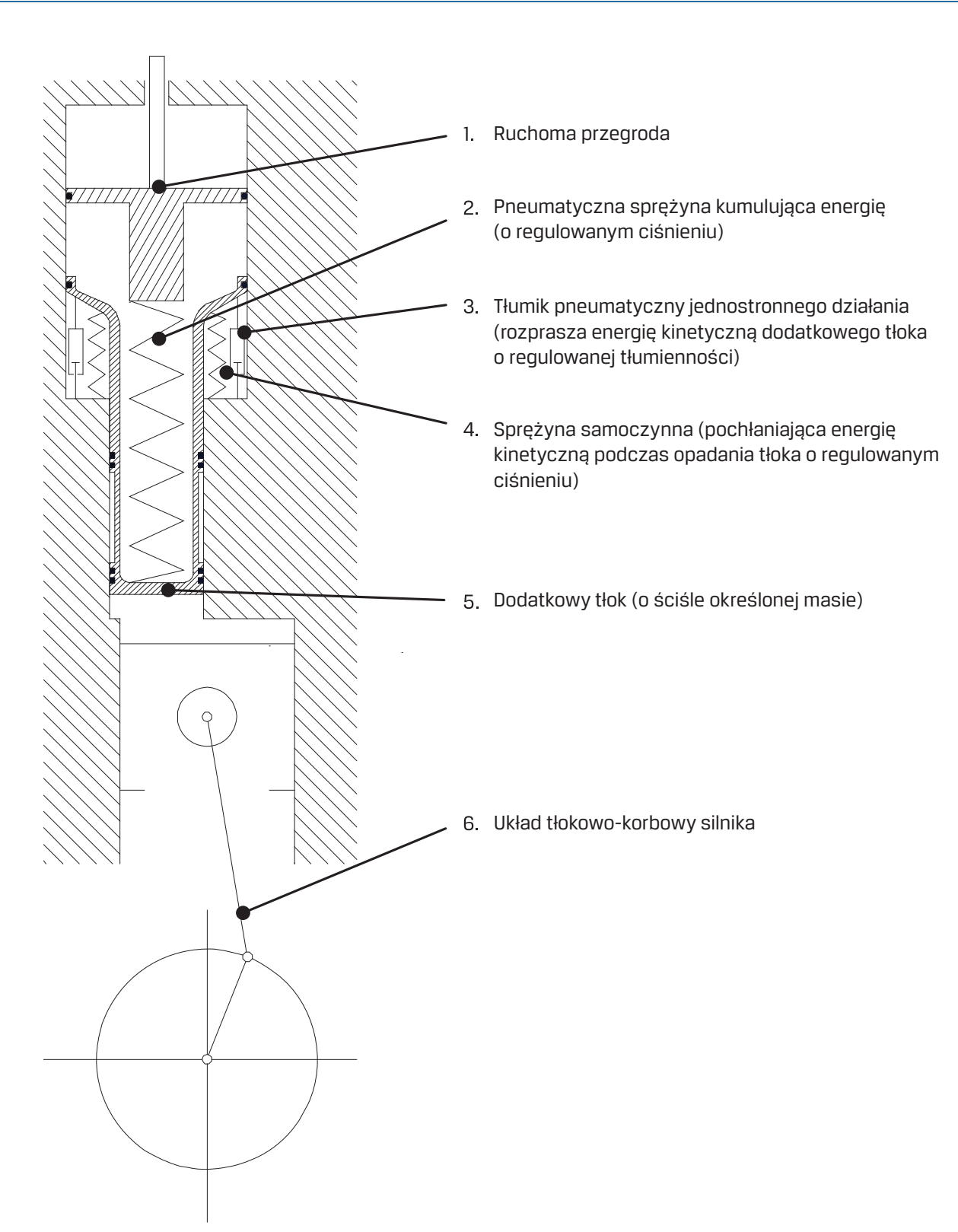

Rys.1. Schemat działania pneumatycznego akumulatora energii 


\section{Stanowisko pomiarowe}

Stanowisko kontrolno pomiarowe, które powstało podczas realizacji pracy [2] przedstawiono schematycznie wraz z opisem poszczególnych elementów, tylko części zasilającej pneumatyczny akumulator energii na rys. 2. Zbudowany układ umożliwiał pełną regulację ciśnienia w sposób elektroniczny z pulpitu sterującego w zakresie od 0,1 MPa do 1 MPa barów. Regulacji podlegały dwa ciśnienia: zasilające sprężynę pneumatyczną (2) oraz sprężynę pneumatyczną (4).

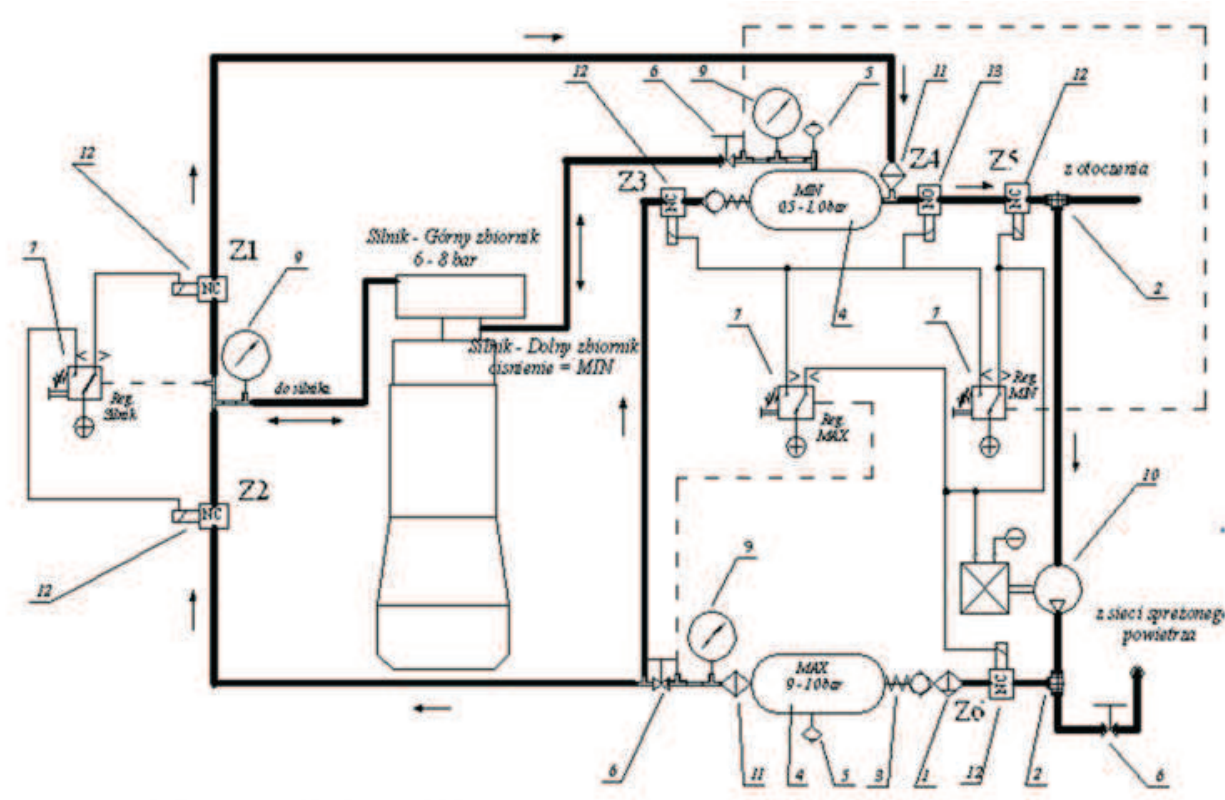

1. Filt pownetza odwadruacz WABCO $4325060000-$ stak: I

2. Zawór dwudiotny VP 434208 - stat: 2

3. Zawór surotyy VP 434021 - statik: 2

4. Zbiomik powietra 030350 609- stak: 2

5. Zawor odwadnigac VP 934300 - stuk !

6. Zawór inl kowey - sctuk 3

10. Spretarka - sauk I

11. Filt prasuodowy VP 8101 - stzik: 4

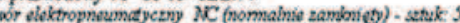

13. Zawór elektropneumatyczny NO (nomainie otwarty)-sctuk: I

Rys.2. Schemat stanowiska.

\section{Laserowy pomiar położenia dodatkowego tłoka}

Położenie tłoka w głowicy (5) dwusuwowego silnika mierzono laserowym przetwornikiem położenia Baumer OADM 2016460/S14F o zakresie pomiarowym 30 -130 mm, częstotliwości własnej 1,1 kHz i błędzie liniowości wskazań 0,2 mm.

Schemat pomiaru jest przedstawiony na rys. 3. Pomiar odbywa się w odizolowanej od otoczenia z powodu panującego w niej nadciśnienia przestrzeni pomiarowej, w której 
przemieszcza się dodatkowy tłok. Przechodząc przez wziernik wiązka laserowa, odbija się od powierzchni pomiarowej a następnie powraca do czujnika odchylona o pewien kat, który jest miarą odległości od czujnika. Pomiar dokonywany w taki sposób jest obarczony błędami wynikającymi z załamania światła na powierzchniach wziernika, ale przeprowadzone próby pozwoliły oszacować błąd i przy pomiarze różnicowym można go pominąć bez

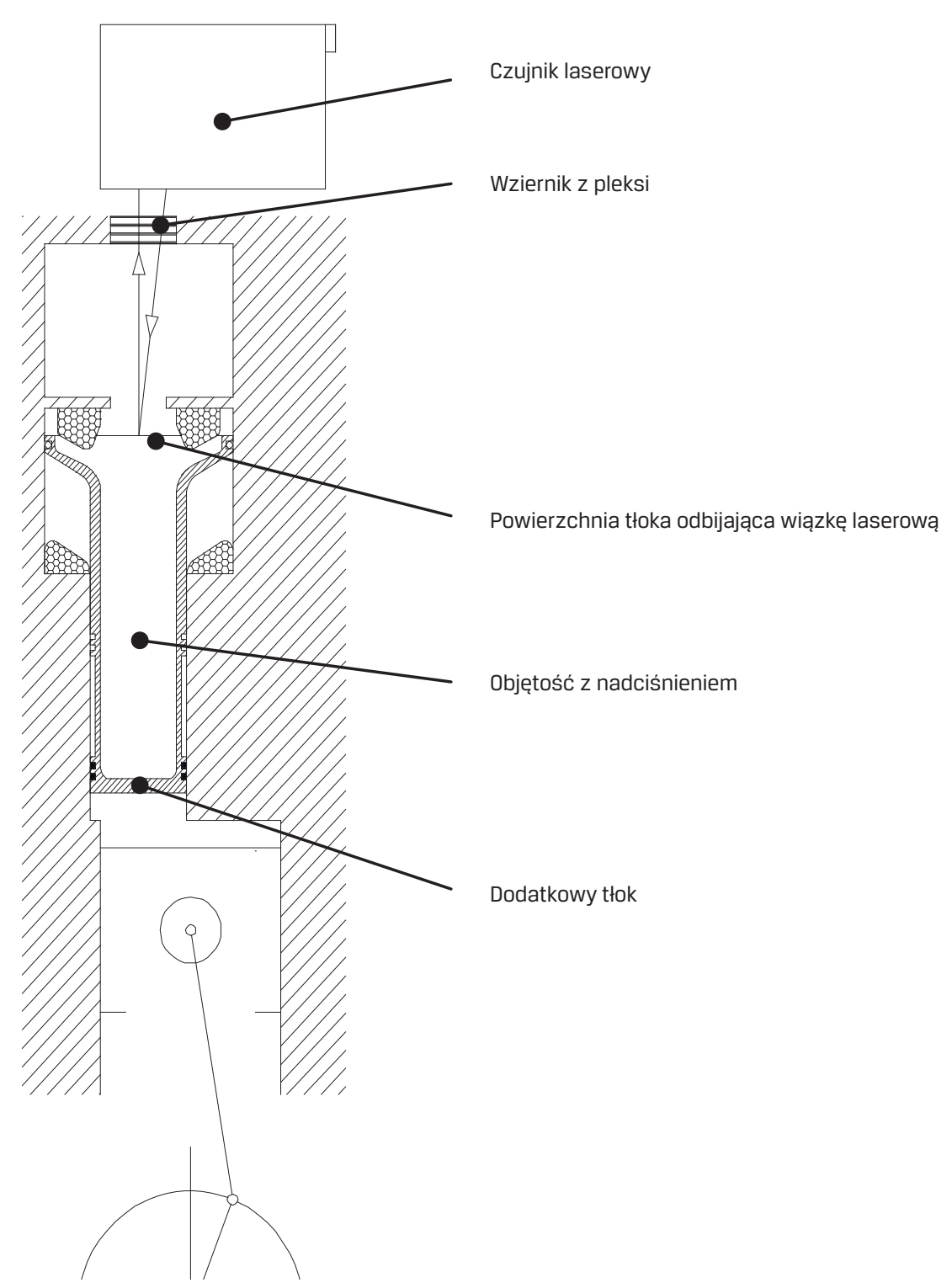

Rys.3. Laserowy pomiar położenia tłoka w akumulatorze 
szkody dla samych pomiarów. W całej przestrzeni pomiarowej znajdowały się drobiny oleju smarującego i chłodzącego układ tłok - cylinder. Osadzał się on również na powierzchni odbijającej wiązkę pomiarową i wzierniku z pleksi, co było przyczyną stałej kontroli, a przy zaniku sygnału, przerw w pomiarze. Podczas tych przerw usuwano olej ze wszystkich powierzchni jednocześnie weryfikując stan techniczny pneumatycznego akumulatora.

Dodatkowym problemem okazały się drgania generowane przez silnik. Powodowały zjawisko interferencji, które usunięto przez zastosowanie specjalnej konstrukcji mocującej czujnik do głowicy. Problem ten można rozwiązać na dwa sposoby: w pierwszym należy zamocować go bardzo sztywno, ale istniało niebezpieczeństwo uszkodzenia czujnika, a w drugim zamocować czujnik elastycznie z tłumikiem. W badaniach prototypu zastosowano ten drugi sposób ze względu na użyty czujnik, który miał znaczące ograniczenia dopuszczalnych wartości przyspieszeń, jakim może być poddany.

W drodze doświadczeń wybrano górną powierzchnię tłoka na element odbijający wiązkę laserową, gdyż w tej części nie gromadził się olej. Wadą tego wyboru jest mała szerokość powierzchni pomiarowej, co wymaga precyzyjnego ustawienia czujnika i nie uwzględnione są odkształcenia własne tłoka. Po analizie wszystkich problemów związanych z tym pomiarem, stwierdzono że, nowy czujnik powinien mieć częstość próbkowania, co najmniej $15 \mathrm{kHz}$ i dokładność rzędu 0,1 mm. Dopiero zastosowanie takiego czujnika odpornego na duże wartości przyspieszeń i sztywno zamocowanego do głowicy zapewni właściwą dokładność pomiaru.

\section{Metodyka badań}

Założeniem badań był warunek, że wartość maksymalnego ciśnienia nie przekracza wartości ciśnienia występującego w silniku podczas pełnego otwarcia przepustnicy.

W pierwszej fazie badań określono tę wartość i wyniosła ona ok. 4.2 MPa. Następnie wyznaczono parametry geometryczne oraz podparcia dodatkowego tłoka. Dokonano także kilkudziesięciu pomiarów przebiegu ciśnienia w zmodyfikowanym cylindrze pod kątem udoskonalenia konstrukcji akumulatora. Po tych zabiegach przeprowadzono pomiar porównawczy w silniku dwusuwowym. Badano równocześnie przebieg ciśnienia w dwóch skrajnych cylindrach, których komory spalania przedstawiono na rys. 4. Pozwolito to na bezpośrednie porównanie otrzymanych wyników obu cylindrów w wybranych zakresach prędkości obrotowych i obciążeń. Do analizy wybrano tylko te punkty pracy, dla których nie było zakłócone przepłukanie dwusuwowego silnika, tworzące asymetrię w zasilaniu obu cylindrów. Ponadto, badano wpływ kąta wyprzedzenia zapłonu i masy dodatkowego tłoka w akumulatorze na przebieg ciśnienia w cylindrze. 


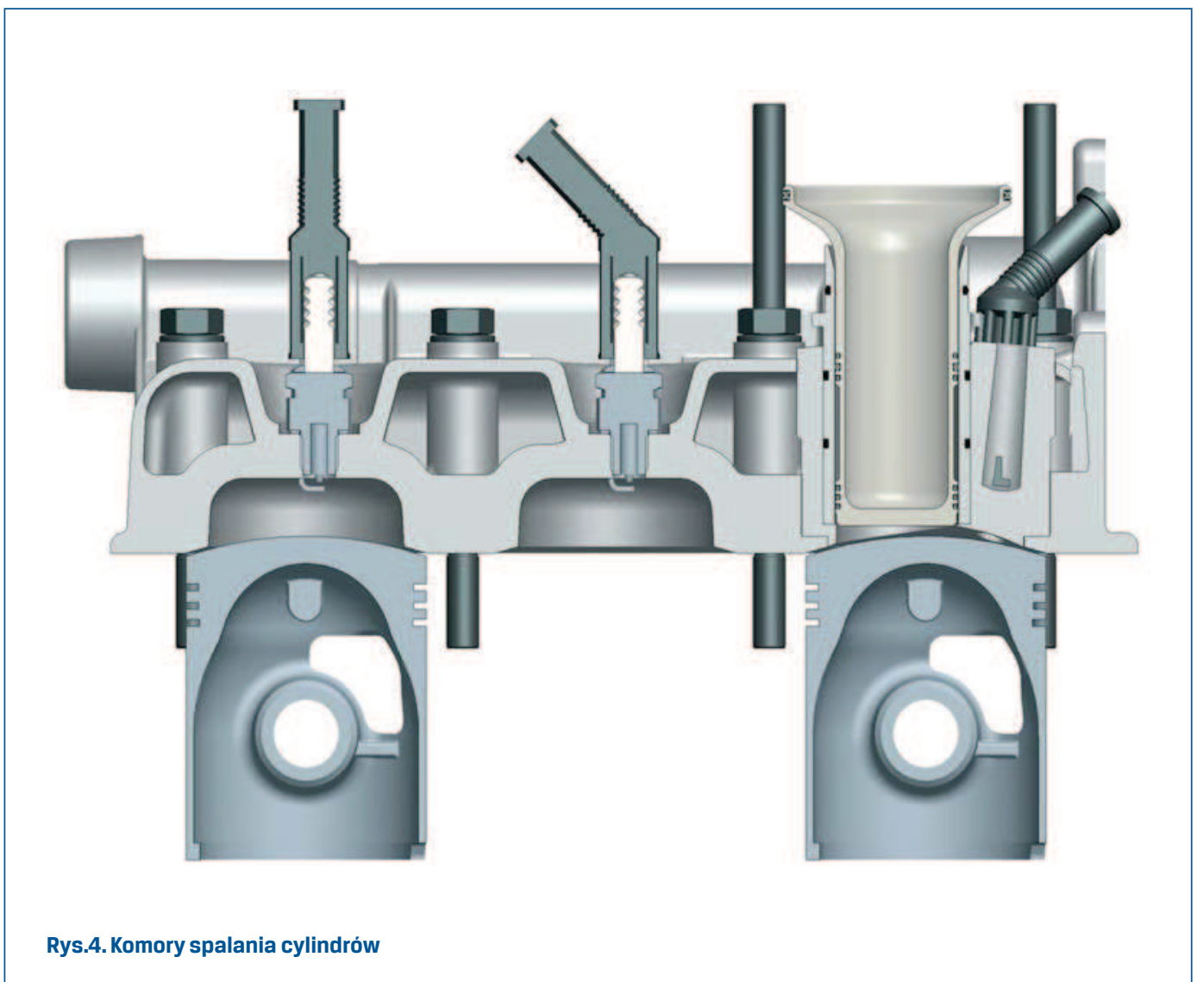

\section{Przykładowy wynik pomiaru dla silnika dwusuwowego}

Na rys. 4 przedstawiono przykładowy pomiar przemieszczenia dodatkowego tłoka (linia przerywana), nałożony na przebieg ciśnienia (linia ciągła) w cyklu zamkniętym w zależności od objętości względnej, wykonany na dwusuwowym silniku o zapłonie iskrowym o następujących parametrach: objętość skokowa pojedynczego cylindra $332 \mathrm{~cm}^{3}$, kąt otwarcia przepustnicy ok. 15\%, prędkość obrotowa 1400 obr/min, maksymalny stopień sprężania ok. 20.

Przedstawiony na rys. 5 rzeczywisty przebieg ciśnienia w cylindrze wyraźnie odbiega od standardowego przebiegu ciśnienia dla silnika dwusuwowego o zapłonie iskrowym. Bez wątpienia jest to spowodowane działalnością dodatkowego tłoka umieszczonego w komorze spalania. Ruch dodatkowego tłoka w końcowej fazie był w przybliżeniu ruchem o gasnącej amplitudzie z widocznym logarytmicznym dekrementem tłumienia, co świadczyło o poprawnym działaniu układu rozpraszającego energię kinetyczną opadającego tłoka (5), 


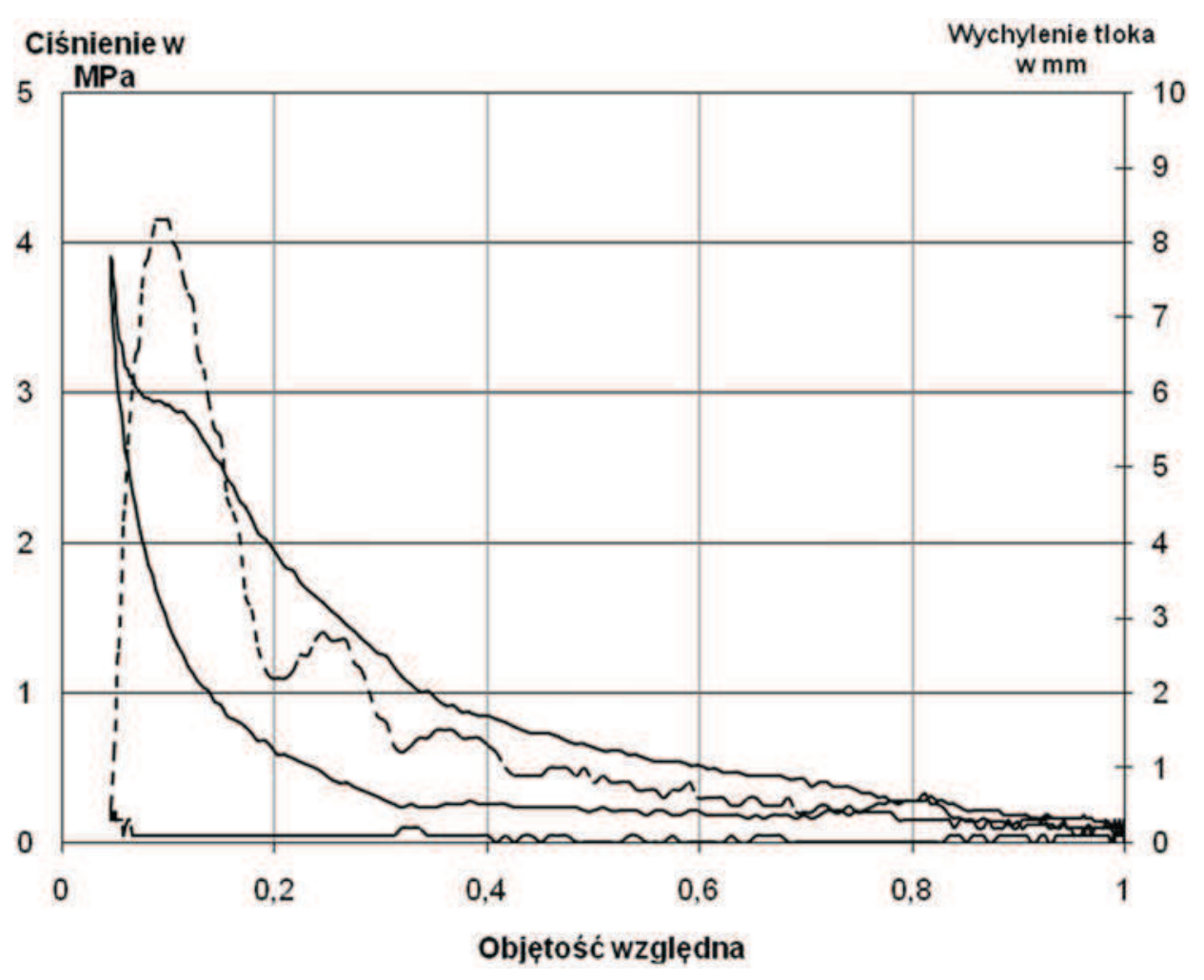

Rys.5. Rzeczywisty przebieg ciśnienia czynnika w cylindrze i przemieszczenie dodatkowego tłoka

sprężyny (4) i tłumika (3). Na rys. 5 wykres ruchu dodatkowego tłoka (linia przerywana) jest wyraźnie pofałdowany. Jest to rezultat niedostatecznej częstości pomiarowej laserowego czujnika położenia, który przy większych prędkościach „gubił sygnał".

Sam pomiar ciśnienia był również obarczony zakłóceniami natury elektrycznej szczególnie uwidaczniającymi się w niskim zakresie wartości ciśnień. Pomimo to widać charakterystyczną dla rozwiązania „półkę". Jest to miejsce, w którym następuje rekuparacja energii - chwilowo nie zmienia się znacząco objętość a skutkiem jest utrzymywanie się ciśnienia na stałym poziomie (stąd nazwa). 


\section{Podsumowanie}

Konstrukcja pneumatycznego akumulatora okazała się na tyle trwała, że umożliwiła badania wstępne. Stanowisko badawcze rozbudowano do stanu umożliwiającego pełną kontrolę wszystkich parametrów silnika i akumulatora energii. Wstępnie dobrano parametry akumulatora: masę i wartości ciśnień w sprężynach podpierających dodatkowy tłok oraz przeanalizowano ich wpływ na przebieg ciśnienia cylindrze w końcu suwu sprężania i na początku suwu rozprężania. W trakcie tych badań stwierdzono ponad 30\% wzrost sprawności silnika przy częściowych obciążeniach i brak objawów spalania stukowego pomimo bardzo dużego stopnia sprężania (21). Zakłócenia w przepłukaniu silnika, uniemożliwiły badania w zakresach przekraczających $50 \%$ kąta otwarcia przepustnicy. Ustalono ponadto, że w końcowej fazie opadania tłoka (5) występujące w sprężynie (4) ciśnienie, wielokrotnie przekraczało wartość ciśnienia zasilającego sprężynę (2), co świadczyło o bardzo dużych wartościach sił masowych. Najbardziej kłopotliwym okazał się pomiar położenia dodatkowego tłoka realizowany czujnikiem laserowym. Zbyt niska częstość próbkowania tego czujnika uniemożliwiła analizę termodynamiczną przy większych prędkościach obrotowych. Dalsze badania będą kontynuowane na silniku czterosuwowym z czujnikiem laserowym o wymaganych parametrach w pełnym zakresie obciążeń.

\section{Literatura}

[1] GŁOGOWSKI M.: Zgłoszenie patentowe nr P388876 z dnia 27-08-2009 r.

[2] Sprawozdanie(merytoryczne) z wykonania projektu badawczego "własnego" N512 012 31/1068 "Tłokowy silnik spalinowy o regulowanej objętości spalania oraz wewnętrznej akumulacji i rekuperacji energii"

[3] OSIŃSKI Z.: Teoria drgań Warszawa PWN 1980 r.

[4] WIŚNIEWSKI S.: Termodynamika techniczna Warszawa PWN 1987 r.

[5] KORDZIŃSKI CZ. POGORZELSKI, J.: Małe silniki spalinowe WKŁ1982 r.

[6] JĘDRZEJOWSKI J.: Mechanika układów korbowych WKŁ 1987 r. 